\title{
CORPORATE LEADERSHIP EXPOSED DURING COVID 19
}

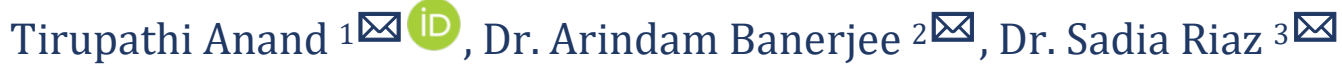 \\ 1 DBA Scholar and Adjunct Faculty, SP Jain School of Global Management, India \\ 2 Professor, SP Jain School of Global Management, India \\ ${ }^{3}$ Associate Professor, SP Jain School of Global Management, India
}

DOI: https://doi.org/10.29121/granthaalayah.v8.i9.2020.1602

Article Type: Research Article

Article Citation: Tirupathi Anand, Dr. Arindam Banerjee, and Dr. Sadia Riaz. (2020). CORPORATE LEADERSHIP EXPOSED DURING COVID 19. International Journal of Research -GRANTHAALAYAH, 8(9), 351-353. https://doi.org/10.29121/granthaa layah.v8.i9.2020.1602

Received Date: 15 September 2020

Accepted Date: 30 September 2020

Keywords:

COVID 19

Pandemic

Corporate Strategy

Corporate Leadership

\section{ABSTRACT}

The sudden onset of the pandemic called COVID 19 took the entire world by shock and surprise. The reaction time was very less as most of the countries went into a lockdown to contain the spread of the virus. People were least prepared for the pandemic and its waterfall effects. The businesses were mostly reactive and internally started creating panic among employees and other stakeholders. This article is an attempt to explore the after effects of COVID 19 and how the Corporate Leadership got completely exposed during the pandemic.

\section{INTRODUCTION}

\subsection{COVID 19}

The Corporate World which is full of leaders with fancy C-Suite designations and fat salaries and bonuses got completely caught off-guard by Covid-19 (C19) pandemic. When the C19 was declared as a Pandemic in the month of March 2020 the entire corporate world came to a grinding halt.

The Corporate Leaders talk very well in Town Hall Meetings, Internal Management Meetings, Board Meetings, Public Forums and everywhere wherever given a chance on how business should face challenges, be prepared for disruptions, business continuity, disaster recovery, risk management, succession planning and so on.

Most of the companies started scrambling for Business Continuity Plan when the pandemic was announced. Most of the Corporate Leaders were caught napping as they were clueless on next steps and were trembling and showing knee-jerking reactions. Many of them called for meetings and told the rest of the department or company that they are not clear on how to handle the situation (D'Auria, G., \& De Smet, A. March 2020). 


\section{CORPORATE REACTION TO PANDEMIC}

Very few companies and their leadership actually demonstrated that the first and foremost thing is the safety and security of the employees, customers and suppliers. Proactiveness which comes from meticulous planning and preparedness was demonstrated by some of the companies and their corporate leadership.

In many of the companies, reckless decisions were made in terms of slashing of manpower either through furloughs or termination, realignment, restricting, reduction in salaries, increasing workload, remote working, etc. One of the retail chains announced that the top 1000 employees will not be paid any salary for three months and the rest will take a pay cut of anywhere between $30 \%$ to $70 \%$ depending on their criticality and position in the organisation.

Another organisation decided that all the frontline staff are not required due to lock down and hence kept $20 \%$ and removed $80 \%$. Even the $20 \%$ that were retained had to take a $70 \%$ pay cut while the support staff and back end staff were forced to take a pay cut of minimum $30 \%$ depending on their position and job role.

The Corporate Management came up with different decisions on a weekly basis as the situation became worse world over in April and May 2020. Some of the earlier decisions were reversed and many of the decisions over the last few weeks have clearly shown negative results.

\section{CORPORATE LEADERSHIP FAILURE}

Instead of motivating the employees and encouraging them to stay safe and resilient the Corporate Leaders only instilled more insecurity and fear. They exhibited total unpreparedness and cluelessness and thus created a panic situation for the others though as leaders they were supposed to lead by example. The lack of maturity, resilience, foresight and wisdom has clearly exposed the Corporate Leadership during this C19 Pandemic Horesh, D., \& Brown, A. D. 2020).

There are a few lessons that the Corporate Leaders have to learn from this experience and at the same time the mistakes done by the present generation of Corporate Leaders is also a great lesson for the next generation. The Pandemic led to Economic Crisis all over the world wiping out a few trillion dollars from the Global Economy. The economic crisis will keep repeating at different points of time in the future due to various reasons and the Corporate Leadership should get ready to face those crises as and when they unfold.

Digital Transformation which was the buzz world for the last few years in many corporate entities became a sudden need of the hour (livari, N., et. al 2020). The transformation had to take place urgently due to the C19 Pandemic. Cash Flow Management which has been ignored by some of the companies, due to comfortable liquidity position in the past, became the most critical aspect. Business Process Re-engineering which was a fashionable phrase in the past became the crucial aspect to be addressed.

Some businesses have seized the opportunity and capitalised on the situation very nicely. Delivery company, pharma companies, PPE producers to name a few are the ones who took this opportunity and flourished well.

\section{CONCLUSION}

In summary, while there were sporadic instances of dynamic leadership and eventual learning, majority of the Corporate Leadership exposed themselves by showing their exuberance of ignorance. Most of the Corporate Leadership proved that they can manage things as long as it is "business as usual" but if there is crisis or sudden disruption or huge shocks they would actually panic and become clueless.

The road to recovery will be easy and smooth if the Corporate Leadership can quickly swing into action by learning from the mistakes. Leadership is all about learning and when the learnings are immediately put into practice leadership will flourish.

\section{SOURCES OF FUNDING}

This research received no specific grant from any funding agency in the public, commercial, or not-for-profit sectors. 


\section{CONFLICT OF INTEREST}

The author have declared that no competing interests exist.

\section{ACKNOWLEDGMENT}

None.

\section{REFERENCES}

[1] https://www.who.int/dg/speeches/detail/who-director-general-s-opening-remarks-at-the-media-briefingon-covid-19---11-march-2020

[2] D’Auria, G., \& De Smet, A. (1994). Leadership in a crisis: Responding to the coronavirus outbreak and future challenges. Psychology, 22(2), 273-87.

[3] Horesh, D., \& Brown, A. D. (2020). Traumatic stress in the age of COVID-19: A call to close critical gaps and adapt to new realities. Psychological Trauma: Theory, Research, Practice, and Policy, 12(4), 331.

[4] Iivari, N., Sharma, S., \& Ventä-Olkkonen, L. (2020). Digital transformation of everyday life-How COVID-19 pandemic transformed the basic education of the young generation and why information management research should care?. International Journal of Information Management, 102183. 